presence of immunoglobulins, fibrin, and complement in casts in the biopsy specimen and their presence in the urine. Casts are not always observed in a biopsy specimen, and hence this comparison is most meaningful in cases in which a positive result is recorded for casts in the biopsy specimen and a negative result for casts in the urine. This occurred in only one out of 31 patients.

Glomerulonephritis is a common disease and is being identified more often in asymptomatic patients as simple dipstick methods of urine analysis become more widely used. Although a renal biopsy gives the only definitive diagnosis of glomerulonephritis, careful analysis of the microscopic findings in the urine, particularly glomerular erythrocyte counts, ${ }^{910}$ will identify most cases of glomerulonephritis. Staining of casts for complement, immunoglobulins, and fibrin provides another noninvasive method of diagnosing glomerulonephritis.

We are indebted to Professor P Kincaid-Smith for the histological assessment of renal biopsy specimens, Dr J P Dowling for the immunofluorescence reports on renal biopsy specimens, and the Renal Research Institute for financial support.

\section{References}

${ }^{1}$ Addis T. The renal lesion in Bright's disease. Harvey Lect $1929 ; 23$ 222-50.

${ }^{2}$ McQueen EG. Composition of urinary casts. Lancet 1966;i:397-8.

${ }^{3}$ Rutecki GJ, Goldsmith C, Schreiner GE. Characterization of proteins in urinary casts. $N$ Engl f Med $1971 ; 284: 1049-52$.

${ }^{4}$ Fasset RG, Owen JE, Fairley J, Birch DF, Fairley KF. Urinary red-cell morphology during exercise. $\mathrm{Br} M e d$ f 1982;285:1455-7.

5 Imhof PR, Hushak J, Schumann G, Dukor P, Wagner J, Keller HM. Excretion of urinary casts after the administration of diuretics. $\mathrm{Br}$ Med ₹ 1972;ii:199-202.

${ }^{6}$ Friedman IS, Zuckerman S, Cohn TD. The production of urinary casts during the use of cation exchange resins. Am f Med Sci $1951 ; 221$ : 672-7.

${ }^{7}$ Mowbray JF, Kapoor A, Porteck A, Peart WS. Significance of haematuria in hypertensive patients. Lancet $1980 ; \mathrm{i}: 231-2$.

${ }^{8}$ Birch DF, Fairley KF. Haematuria: glomerular or non-glomerular? Lancet 1979 ;ii :845-6.

${ }^{9}$ Fairley KF, Birch DF. Hematuria: a simple method for identifying glomerular bleeding. Kidney Int 1982;21:105-8.

10 Birch DF, Fairley KF, Whitworth JA, et al. Urinary erythrocyte morphology in the diagnosis of glomerular haematuria. Clin Nephrol 1983; $20: 78-84$.

(Accepted 3 October 1983)

\title{
Change in risk factors for coronary heart disease during 10 years of a community intervention programme (North Karelia project)
}

\author{
PEKKA PUSKA, JUKKA T SALONEN, AULIKKI NISSINEN, JAAKKO TUOMILEHTO, \\ ERKKI VARTIAINEN, HEIKKI KORHONEN, ANTTI TANSKANEN, PÄIVI RÖNNQVIST, \\ KAJ KOSKELA, JUSSI HUTTUNEN
}

\begin{abstract}
A comprehensive community based programme to control cardiovascular diseases was started in North Karelia, Finland, in 1972. Reductions in smoking, serum cholesterol concentrations, and blood pressure were among the central intermediate objectives. The effect of the programme during the 10 year period $1972-82$ was evaluated by examining independent random population samples at the outset (1972) and five (1977) and $10(1982)$
\end{abstract}

\footnotetext{
National Public Health Institute, Department of Epidemiology, Mannerheimintie 166, 00280 Helsinki 28, Finland

PEKKA PUSKA, MD, MPOLSC, professor, director of the North Karelia project, director of department of epidemiology

AULIKKI NISSINEN, MD, NT, senior researcher, co-principal investigator of North Karelia project

ERKKI VARTIAINEN, MD, senior researcher

HEIKKI KORHONEN, MD, researcher

PÄIVI RÖNNQVIST, MPOLSC, researcher

JUSSI HUTTUNEN, MD, director, professor

University of Kuopio, Research Institute of Public Health, Box 138, 70101 Kuopio 10, Finland

JUKKA T SALONEN, MD, professor, co-principal investigator of North Karelia project

JAAKKO TUOMILEHTO, MD, MPOLSC, consultant, co-principal investigator of North Karelia project

ANTTI TANSKANEN, MD, acting professor

National Board of Health, Office of Health Education, Box 224, 00531 Helsinki 53

KAJ KOSKELA, MD, MPOLSC, chief of office of health education

Correspondence to: Professor Pekka Puska.
}

years later both in the programme and in a matched reference area. Over 10000 subjects were studied in 1972 and 1977 (participation rate about 90\%) and roughly 8000 subjects in 1982 (participation rate about $80 \%$ ).

Analyses were conducted of the estimated effect of the programme on the risk factor population means by comparing the baseline and five year and 10 year follow up results in the age range 30-59 years. The effect of the programme (net reduction in North Karelia) at 10 years among the middle aged male population was estimated to be a $28 \%$ reduction in smoking $(p<0.001)$, a $3 \%$ reduction in mean serum cholesterol concentration ( $p<0.001)$, a $3 \%$ fall in mean systolic blood pressure $(p<0.001)$, and a $1 \%$ fall in mean diastolic blood pressure $(p<0.05)$. Among the female population the reductions were respectively, $14 \%$ (NS), $1 \%$ (NS), $5 \%$ (p $<0.001$ ), and $2 \%(p<0.05)$.

During the first five years of the project (1972-7) the programme effectively reduced the population mean values of the major coronary risk factors. At 10 years the effects had persisted for serum cholesterol concentrations and blood pressure and were increased for smoking.

\section{Introduction}

After the second world war cardiovascular diseases, predominantly coronary heart disease, became the leading public health problem in most of the industrialised world. Mortality statistics and other studies showed that in the 1960s the highest heart disease mortality rates were observed in Finland, predominantly in men. ${ }^{1-3}$ Within Finland the highest rates were registered in eastern Finland and were particularly high in the county of North Karelia. ${ }^{45}$ A major national project was there- 
fore started in Finland to develop and test methods for community wide control of this modern epidemic. The North Karelia project was formulated and launched in 1972 after a local petition and in close cooperation with Finnish experts and the World Health Organisation. ${ }^{6}$ The aim of the project has been to carry out a comprehensive community based programme for the control of cardiovascular diseases in the whole of North Karelia and carefully to evaluate the results.

The main objective of the programme in North Karelia has been to decrease the mortality and morbidity rates of major cardiovascular diseases among the whole population in the area, but with special reference to middle aged men. "The emphasis has been on primary prevention of ischaemic heart disease in the population through a general reduction of the well established risk factors-smoking, a high serum cholesterol concentration, and high blood pressure. ${ }^{\triangleleft}$ This has been done through a comprehensive community based educational programme based on local community action and local service structure. Practical skills have been taught, social support for change has been provided, and environmental modifications arranged as part of the comprehensive community organisation for change. ${ }^{7} y$

The aim of evaluating the programme was to assess its feasibility, effects, costs, process, and other consequences in North Karelia. 'The evaluation has used several data sources. Repeated surveys of large independent cross sectional population samples were used to assess the risk factor and health behaviour changes among the population. To allow for "spontaneous" or national changes a matched reference area was used, so that analysis followed a "quasi-experimental" design.

Results of the first five years of the project (1972-7) have been published. " $1 "$ "In the spring of 1982 a follow up survey was carried out in North Karelia and the reference area to assess the results at 10 years. At the same time the most recent available mortality data were collected and analysed for changes in mortality from coronary heart disease in North Karelia and other counties of Finland. This paper reports the results for risk factors over the 10 years. The mortality findings are reported elsewhere. ${ }^{12}$

\section{Materials and methods}

A baseline survey for assessing changes in risk factors was carried out in the spring of 1972 in North Karelia and a matched reference area-another county in eastern Finland. A random $6 \cdot 6^{\circ}$, sample was drawn from the populations of the two counties using the national population register. The sample included men and women aged 25-59 years (born during 1913-47). In 1977 another cross sectional survey, the five year follow up survey, was carried out in the two areas. The survey methods were the same as those in the baseline survey. An independent $6.6^{\circ}{ }_{0}$ random sample was used, including both men and women aged 30-64 years (born during 1913-47).

In the spring of 1982 a third survey, the 10 year follow up survey, was carried out in the two areas. An independent random sample was again drawn. This time the sample was drawn for the age group 25-64 years and stratified so that for each sex and 10 year age specific group the sample size would be about 500 . We used this procedure to comply with the protocol of the international MONICA project initiated by WHO, since our survey served as the baseline survey for the Finnish contribution to that project. ${ }^{13}$

The practical methods used in the surveys are detailed elsewhere ${ }^{7}$ and also followed the WHO MONICA protocol. ${ }^{13}$ They included a questionnaire answered at home (on general background, socioeconomic state, medical history, health behaviour, and so on) and measurements of height, weight, and blood pressure. A venous blood specimen was taken for determination of the serum cholesterol concentration. Casual blood pressure was measured sitting according to the standardised technique, in which the fifth phase of the Korotkoff sounds was recorded as the diastolic pressure.

Each survey followed the same methods as closely as possible, and in each survey the two areas were treated in the same way-for example, blood samples from the two areas were analysed in mixed order. Serum cholesterol was determined in 1972 and 1977 from frozen samples and in 1982 from fresh serum samples in a central laboratory, standardised against international WHO references. In
1972 and 1977 a shorter cuff bladder was used for the blood pressure measurement than in $1982(23 \mathrm{~cm} v 42 \mathrm{~cm})$.

Participation rates in the baseline survey were $94 \%$ in North Karelia and $91 \%$ in the reference area (in roughly $6 \%$ of subjects only questionnaire data were available). In the 1977 survey the rates were $89^{\circ}$, in North Karelia and $91 \%$, in the reference area, and in the 1982 survey the rates were $80^{\circ}{ }^{\circ}$ in North Karelia and $82^{\circ} \%$ in the reference area. The present analysis is concerned with subjects aged 30-59 taken from all three survey samples. Table I shows the numbers of men and women studied in the three surveys in North Karelia and the reference area.

The means of the four risk factor variables-smoking, serum cholesterol concentrations, and systolic and diastolic blood pressures -were computed and analysed by area, time, sex, and age. Four way analysis of variance was used to test the significance of variation in means. "Area" was coded 0 when it referred to the reference area and 1 when it referred to North Karelia, and "time" was coded 0 when it referred to 1972 and 1 when it referred to 1977 or 1982 (in respective analyses). Thus the interaction of area and time showed the significance of the net change of risk factor means related to the programme.

TABLE I-Numbers of men and women studied in the three cross sectional surveys in North Karelia and the reference area

\begin{tabular}{|c|c|c|c|c|c|c|}
\hline \multirow{2}{*}{$\underset{(\text { years) }}{\text { Age }}$} & \multicolumn{3}{|c|}{ North Karelia } & \multicolumn{3}{|c|}{ Reference area } \\
\hline & 1972 & 1977 & 1982 & 1972 & 1977 & 1982 \\
\hline & \multicolumn{6}{|c|}{ Numbers of men } \\
\hline $30-39$ & 588 & 640 & 420 & 891 & 954 & 490 \\
\hline $40-49$ & 699 & 607 & 371 & 1024 & 885 & 364 \\
\hline $50-59$ & 547 & 538 & 459 & 750 & 777 & 343 \\
\hline Total & 1834 & 1785 & 1250 & 2665 & 2616 & 1197 \\
\hline \multicolumn{7}{|c|}{ Numbers of women } \\
\hline $30-39$ & 598 & 595 & 422 & 879 & 928 & 340 \\
\hline $40-49$ & 716 & 616 & 423 & 1003 & 903 & 293 \\
\hline $50-59$ & 659 & 634 & 440 & 887 & 925 & 358 \\
\hline Total & 1973 & 1845 & 1285 & 2769 & 2756 & 991 \\
\hline
\end{tabular}

The programme effects were estimated as the net difference of the risk factor means - that is, the difference of the follow up $v$ baseline differences of means between areas. The net difference was also computed (as a percentage) relative to the initial value in North Karelia. The confidence intervals for the programme effect estimates were computed as described. ${ }^{11}$

\section{Results}

Table II shows the mean amounts of reported daily smoking in North Karelia and the reference area in 1972, 1977, and 1982, broken down by age and sex. The reported daily number of cigarettes, cigars, and pipes were summed for this variable, and values are presented as the means per person (including both smokers and non-smokers). The difference in smoking between the baseline and 1977 surveys was significantly greater in North Karelia than in the reference area $(\mathrm{p}<0.01)$. This programme effect was significant for men $(15 \%$; $\mathrm{p}<0.01)$ but not for women $(12 \%$; N ). From 1977 to 1982 a further reduction took place among men, more so in North Karelia. Thus the net reduction in North Karelia during $1972-82$ was $28 \%(\mathrm{p}<0.001)$. Among women smoking increased in 1977-82 in both areas, but more so in the reference area. Thus the net reduction in North Karelia among women during $1972-82$ was $14 \%$ (NS).

To validate the self reported smoking data, the serum thiocyanate concentration was determined in all serum samples in the 1982 survey. The age adjusted partial correlations between reported daily amount of smoking and serum thiocyanate value in North Karelia and the reference area were 0.72 and 0.67 among men and 0.69 and 0.70 among women.

The overall programme effect on mean serum cholesterol concentrations during 1972-7 was highly significant $(\mathrm{p}<0.001)$. Analysed by sex (table III) the effect was significant among men $(4 \% ; \mathrm{p}<0.001)$ but not in the whole age range of women (1\%). During 1977-82 the serum cholesterol concentrations showed an almost parallel reduction, giving for $1972-82$ a net reduction of $3 \%$ among men $(p<0.001)$ and $1 \%$ among women (NS).

The programme effect on both systolic and diastolic blood pressure 
TABLE II-Mean amount of reported daily smoking in North Karelia and reference area in independent baseline (1972), five year (1977), and 10 year (1982) follow up survey samples by sex and age. Values given in smoking times a day

\begin{tabular}{|c|c|c|c|c|c|c|c|c|}
\hline \multirow{2}{*}{ Age (years) } & \multicolumn{3}{|c|}{ North Karelia } & \multicolumn{3}{|c|}{ Reference area } & \multicolumn{2}{|c|}{ Net reduction $(\%)^{*}$} \\
\hline & 1972 & 1977 & 1982 & 1972 & 1977 & 1982 & $1972-7$ & $1972-82$ \\
\hline $\begin{array}{l}30-39 \\
40-49 \\
50-59\end{array}$ & $\begin{array}{c}\text { Men } \\
10 \cdot 6 \\
10 \cdot 2 \\
9 \cdot 0\end{array}$ & $\begin{array}{l}9.0 \\
8.5 \\
7.9\end{array}$ & $\begin{array}{l}7 \cdot 2 \\
7 \cdot 0 \\
5 \cdot 7\end{array}$ & $\begin{array}{l}\text { Men } \\
8 \cdot 5 \\
9 \cdot 0 \\
7 \cdot 7\end{array}$ & $\begin{array}{l}9 \cdot 0 \\
8 \cdot 6 \\
7 \cdot 7\end{array}$ & $\begin{array}{l}8 \cdot 6 \\
8 \cdot 0 \\
6 \cdot 5\end{array}$ & $\begin{array}{l}19 \\
12 \\
12\end{array}$ & $\begin{array}{l}33 \\
21 \\
23\end{array}$ \\
\hline Total & $10 \cdot 0$ & 8.5 & $6 \cdot 6$ & $8 \cdot 5$ & $8 \cdot 5$ & $7 \cdot 8$ & 15 & 28 \\
\hline $\begin{array}{l}30-39 \\
40-49 \\
50-59\end{array}$ & $\begin{array}{l}\text { Women } \\
1 \cdot 4 \\
1 \cdot 2 \\
0 \cdot 7\end{array}$ & $\begin{array}{l}1 \cdot 6 \\
1.1 \\
0.7\end{array}$ & $\begin{array}{l}2.6 \\
1.5 \\
0.9\end{array}$ & $\begin{array}{l}\text { Wome } \\
1.5 \\
1.0 \\
1.0\end{array}$ & $\begin{array}{l}2 \cdot 0 \\
1 \cdot 2 \\
0 \cdot 8\end{array}$ & $\begin{array}{l}2 \cdot 8 \\
1 \cdot 7 \\
1 \cdot 2\end{array}$ & $\begin{array}{r}18 \\
24 \\
-26\end{array}$ & $\begin{array}{r}2 \\
36 \\
1\end{array}$ \\
\hline Total & $1 \cdot 1$ & $1 \cdot 1$ & $1 \cdot 7$ & $1 \cdot 2$ & $1 \cdot 3$ & 1.9 & 12 & 14 \\
\hline
\end{tabular}

* (North Karelia 1982/77-1972) - (reference area 1982/77-1972)/North Karelia 1972.

Four way analysis of variance (area, time, area-time, area-time-sex)-1972-7: $\mathrm{p}<0.05, \mathrm{NS}, \mathrm{p}<0.01, \mathrm{p}<0.05 ; 1972-82: \mathrm{NS}, \mathrm{p}<0.001, \mathrm{p}<0.001, \mathrm{p}<0.001$.
Analysis of variance for linear trend 1972-7-82 (men, women)-North Karelia: $\mathrm{p}<0.001, \mathrm{p}<0.001 ;$ reference area: NS, $\mathrm{p}<0.001$.

TABLE III-Mean serum cholesterol concentrations in North Karelia and reference area in independent baseline (1972), five year (1977), and 10 year (1982) follow $u$ survey samples by sex and age. Values given in mmol/l. (Standard deviations in parentheses)

\begin{tabular}{|c|c|c|c|c|c|c|c|c|}
\hline \multirow{2}{*}{ Age (years) } & \multicolumn{3}{|c|}{ North Karelia } & \multicolumn{3}{|c|}{ Reference area } & \multicolumn{2}{|c|}{ Net reduction $\left({ }^{0}{ }_{0}\right)^{*}$} \\
\hline & 1972 & 1977 & 1982 & 1972 & 1977 & 1982 & $1972-7$ & $1972-82$ \\
\hline $\begin{array}{l}30-39 \\
40-49 \\
50-59\end{array}$ & $\begin{array}{l}\text { Men } \\
6 \cdot 8(1 \cdot 4) \\
7 \cdot 2(1 \cdot 3) \\
7 \cdot 3(1 \cdot 3)\end{array}$ & $\begin{array}{l}6 \cdot 4(1 \cdot 2) \\
6 \cdot 8(1 \cdot 2) \\
6 \cdot 9(1 \cdot 3)\end{array}$ & $\begin{array}{l}6 \cdot 0(1 \cdot 1) \\
6 \cdot 5(1 \cdot 2) \\
6 \cdot 4(1 \cdot 2)\end{array}$ & $\begin{array}{l}\text { Men } \\
6 \cdot 6(1 \cdot 2) \\
7 \cdot 0(1 \cdot 4) \\
7 \cdot 1(1 \cdot 2)\end{array}$ & $\begin{array}{l}6.5(1 \cdot 2) \\
6.9(1.2) \\
7.0(1.3)\end{array}$ & $\begin{array}{l}6 \cdot 0(1 \cdot 1) \\
6 \cdot 4(1 \cdot 2) \\
6 \cdot 6(1 \cdot 3)\end{array}$ & $\begin{array}{l}5 \\
3 \\
4\end{array}$ & $\begin{array}{l}4 \\
1 \\
6\end{array}$ \\
\hline Total & $7 \cdot 1(1 \cdot 4)$ & $6 \cdot 7(1 \cdot 3)$ & $6 \cdot 3(1 \cdot 2)$ & $6 \cdot 9(1 \cdot 3)$ & $6 \cdot 8(1 \cdot 3)$ & $6 \cdot 3(1 \cdot 2)$ & 4 & 3 \\
\hline $\begin{array}{l}30-39 \\
40-49 \\
50-59\end{array}$ & $\begin{array}{l}\text { Wmoen } \\
6 \cdot 3(1 \cdot 2) \\
7 \cdot 0(1.4) \\
7 \cdot 7(1.4)\end{array}$ & $\begin{array}{l}5 \cdot 9(1 \cdot 2) \\
6 \cdot 5(1 \cdot 2) \\
7 \cdot 3(1 \cdot 4)\end{array}$ & $\begin{array}{l}5 \cdot 5(1 \cdot 1) \\
6 \cdot 1(1 \cdot 1) \\
6.9(1 \cdot 3)\end{array}$ & $\begin{array}{l}\text { Women } \\
6.3(1.1) \\
6.8(1.3) \\
7.4(1.4)\end{array}$ & $\begin{array}{l}5 \cdot 8(1 \cdot 0) \\
6 \cdot 5(1 \cdot 2) \\
7 \cdot 4(1 \cdot 3)\end{array}$ & $\begin{array}{l}5.5(1.0) \\
5.8(1.1) \\
6.7(1.3)\end{array}$ & $\begin{array}{l}0 \\
1 \\
3\end{array}$ & $\begin{array}{l}1 \\
1 \\
2\end{array}$ \\
\hline Total & $7 \cdot 0(1.4)$ & $6 \cdot 6(1.4)$ & $6 \cdot 2(1 \cdot 3)$ & $6 \cdot 8(1 \cdot 3)$ & $6 \cdot 5(1 \cdot 3)$ & $6.0(1 \cdot 3)$ & 1 & 1 \\
\hline
\end{tabular}

* (North Karelia 1982/77-1972) - (reference area 1982/77-1972)/North Karelia 1972.

Four way analysis of variance (area, time, area-time, area-time-sex) - 1972-7: p 0.001, p 0.001, p 0.001, p 0.01; 1972-82: p 0.001, p $0.001, \mathrm{p} \cdot 0.01, \mathrm{p} \cdot 0.01$.

Analysis of variance for limear (rendits

TABLE IV-Mean systolic blood pressure in North Karelia and reference area in independent baseline (1972), five year (1977), and 10 year (1982) follow up survey samples by sex and age. Values given in $\mathrm{mm} \mathrm{Hg}$. (Standard deviations in parentheses)

\begin{tabular}{|c|c|c|c|c|c|c|c|c|}
\hline \multirow{2}{*}{ Age (years) } & \multicolumn{3}{|c|}{ North Karelia } & \multicolumn{3}{|c|}{ Reference area } & \multicolumn{2}{|c|}{ Net reduction $\left({ }^{\circ}{ }_{0}\right)^{*}$} \\
\hline & 1972 & 1977 & 1982 & 1972 & 1977 & 1982 & $1972-7$ & $1972-82$ \\
\hline $\begin{array}{l}30-39 \\
40-49 \\
50-59 \\
\end{array}$ & $\begin{array}{l}\text { Men } \\
143.7(17 \cdot 2) \\
147.5(19 \cdot 7) \\
156.2(24.5)\end{array}$ & $\begin{array}{l}140.6(16.6) \\
143.5(17.7) \\
146.5(18.8)\end{array}$ & $\begin{array}{l}140.5(16.3) \\
141.7(18 \cdot 1) \\
151.5(20.9)\end{array}$ & $\begin{array}{l}\text { Men } \\
141 \cdot 2(16 \cdot 6) \\
146 \cdot 4(21 \cdot 1) \\
152 \cdot 5(24 \cdot 3)\end{array}$ & $\begin{array}{l}141.7(16.8) \\
146.6(20.0) \\
150.9(20.5)\end{array}$ & $\begin{array}{l}143.4(16 \cdot 6) \\
146.2(18 \cdot 1) \\
i j 2.8(20.3)\end{array}$ & $\begin{array}{l}3 \\
3 \\
5\end{array}$ & $\begin{array}{l}4 \\
4 \\
3\end{array}$ \\
\hline Total & $148 \cdot 6(21 \cdot 0)$ & $143.4(17 \cdot 7)$ & $144.9(19 \cdot 3)$ & $146 \cdot 2(21 \cdot 0)$ & $146 \cdot 1(19 \cdot 4)$ & $146.9(18.6)$ & 3 & 3 \\
\hline $\begin{array}{l}30-39 \\
40-49 \\
50-59\end{array}$ & $\begin{array}{l}\text { Women } \\
138 \cdot 4(18 \cdot 3) \\
153 \cdot 1(24 \cdot 0) \\
167 \cdot 5(26 \cdot 9)\end{array}$ & $\begin{array}{l}131.0(16.3) \\
142.0(19.5) \\
152.3(21.5)\end{array}$ & $\begin{array}{l}132.4(15.7) \\
142.9(20.1) \\
150.0(19.4)\end{array}$ & $\begin{array}{l}\text { Women } \\
132 \cdot 4(16 \cdot 7) \\
147.5(22 \cdot 1) \\
164.5(27 \cdot 3)\end{array}$ & $\begin{array}{l}131 \cdot 3(16 \cdot 2) \\
144 \cdot 1(20 \cdot 2) \\
156 \cdot 0(23 \cdot 0)\end{array}$ & $\begin{array}{l}133.3(16 \cdot 1) \\
142.7(19 \cdot 7) \\
153.3(24 \cdot 1)\end{array}$ & $\begin{array}{l}5 \\
5 \\
4\end{array}$ & $\begin{array}{l}5 \\
4 \\
5\end{array}$ \\
\hline Total & $153 \cdot 0(26 \cdot 1)$ & $142 \cdot 1(21 \cdot 1)$ & $141.9(19.9)$ & $147 \cdot 6(25 \cdot 6)$ & $143.8(22 \cdot 4)$ & $144 \cdot 2(22 \cdot 4)$ & 5 & 5 \\
\hline
\end{tabular}

*(North Karelia 1982/77-72) - (reference area 1982/77-72)/North Karelia 1972.

Four way analysis of variance (area, time, area-time, area-time-sex)-1972-7: p 0.001, p 0.05, p 0.001, p 0.001; 1972-82: p $0.001, \mathrm{p} \cdot 0.001, \mathrm{p} \cdot 0.001, \mathrm{NS}$

Analysis of variance for linear trend 1972-82 (men, women)-North Karelia: $\mathrm{p}-0.001, \mathrm{p}<0.001$; reference area: NS, p 0.001 .

TABLE V-Mean diastolic blood pressure in North Karelia and reference area in independent baseline (1972), five year (1977), and 10 year (1982) follow up survey samples by sex and age. Values given in $\mathrm{mm} \mathrm{Hg}$. (Standard deviations in parentheses)

\begin{tabular}{|c|c|c|c|c|c|c|c|c|}
\hline \multirow{2}{*}{ Age (years) } & \multicolumn{3}{|c|}{ North Karelia } & \multicolumn{3}{|c|}{ Reference area } & \multicolumn{2}{|c|}{ Net reduction $\left({ }^{\prime \prime}{ }^{\circ}\right)^{*}$} \\
\hline & 1972 & 1977 & 1982 & 1972 & 1977 & 1982 & $1972-7$ & $1972-82$ \\
\hline $\begin{array}{l}30-39 \\
40-49 \\
50-59 \\
\end{array}$ & $\begin{array}{l}\text { Men } \\
91 \cdot 0(11 \cdot 4) \\
91 \cdot 8(12 \cdot 2) \\
93.9(12 \cdot 9) \\
\end{array}$ & $\begin{array}{l}86 \cdot 9(10 \cdot 7) \\
90 \cdot 0(10 \cdot 8) \\
89 \cdot 8(10 \cdot 9) \\
\end{array}$ & $\begin{array}{l}83 \cdot 1(12 \cdot 6) \\
87.5(12.5) \\
89.9(12 \cdot 2) \\
\end{array}$ & $\begin{array}{l}\text { Men } \\
91 \cdot 4(10 \cdot 4) \\
94 \cdot 2(12 \cdot 1) \\
94 \cdot 9(12 \cdot 8)\end{array}$ & $\begin{array}{l}90 \cdot 1(11 \cdot 5) \\
93.9(12 \cdot 1) \\
94.9(11 \cdot 6)\end{array}$ & $\begin{array}{l}86 \cdot 1(12 \cdot 6) \\
90 \cdot 8(13 \cdot 1) \\
92 \cdot 1(13 \cdot 0)\end{array}$ & $\begin{array}{l}3 \\
2 \\
4\end{array}$ & $\begin{array}{l}3 \\
1 \\
1\end{array}$ \\
\hline Total & $92 \cdot 1(12 \cdot 2)$ & $88.9(10.9)$ & $86 \cdot 9(12 \cdot 7)$ & $93 \cdot 4(11 \cdot 8)$ & $92 \cdot 8(11 \cdot 9)$ & $89 \cdot 2(13 \cdot 1)$ & 3 & 1 \\
\hline $\begin{array}{l}30-39 \\
40-49 \\
50-59\end{array}$ & $\begin{array}{l}\text { Women } \\
86 \cdot 2(11 \cdot 9) \\
92 \cdot 8(12 \cdot 8) \\
98 \cdot 7(13 \cdot 2)\end{array}$ & $\begin{array}{l}81.9(9 \cdot 7) \\
87.6(10 \cdot 4) \\
90.0(10.6)\end{array}$ & $\begin{array}{l}80.5(11 \cdot 2) \\
86.0(11.8) \\
87.5(11.3)\end{array}$ & $\begin{array}{l}\text { Women } \\
86 \cdot 1(9 \cdot 9) \\
91 \cdot 7(11 \cdot 3) \\
97 \cdot 0(12 \cdot 7)\end{array}$ & $\begin{array}{l}83.3(10.3) \\
89.5(11.4) \\
93.6(11.5)\end{array}$ & $\begin{array}{l}80 \cdot 8(10 \cdot 7) \\
85 \cdot 6(11 \cdot 2) \\
88 \cdot 7(12 \cdot 1)\end{array}$ & $\begin{array}{l}2 \\
2 \\
6\end{array}$ & $\begin{array}{l}1 \\
1 \\
3\end{array}$ \\
\hline Total & $92 \cdot 6(13.6)$ & $86 \cdot 7(10 \cdot 8)$ & $84 \cdot 7(11 \cdot 8)$ & $91 \cdot 5(12 \cdot 1)$ & $88 \cdot 8(11 \cdot 9)$ & $85 \cdot 1(11 \cdot 8)$ & 4 & 2 \\
\hline
\end{tabular}

*(North Karelia 1982/77-1972) - (reference area 1982/77-1972)/North Karelia 1972.

Four way analysis of variance-(area, time, area-time, area-time-sex)-1972-7: $\mathrm{p} 0.001, \mathrm{p} 0.001, \mathrm{p}<0.001, \mathrm{p} \cdot 0.001 ; 1972-82: \mathrm{p} \cdot 0.001, \mathrm{p}-0.001, \mathrm{p}-0.01, \mathrm{NS}$

Analysis of variance for linear trend 1972-7-82 (men, women)-North Karelia: $\mathrm{p} 0.001, \mathrm{p} 0.001$; reference area: $\mathrm{p}-0.001, \mathrm{p}-0.001$. 
means during 1972-7 was highly significant among men and women (tables IV and V). The net reduction of systolic blood pressure was $3 \%$ among men and 5\% among women, and that of diastolic blood pressure $3 \%$ among men and $4 \%$ among women. During 1977-82 systolic blood pressures remained close to those in 1977 in both sexes and in the two areas. Thus the net reductions in systolic blood pressures in men and women remained virtually the same for 1972-82 as for 1972-7 (both sexes: $\mathrm{p}<0.001$ ). For diastolic blood pressure the means in 1982 were lower than in 1977. The net reduction in North Karelia became smaller during $1977-82$, but for the whole period 1972-82 it remained significant for both sexes $(\mathrm{p}<0.05)$.

Table VI summarises the net reductions in risk factor means in North Karelia. As a whole, the favourable programme effect observed during 1972-7 increased for smoking was maintained for serum cholesterol concentration and systolic blood pressure, and was reduced but remained significant for diastolic blood pressure during the second five year period (1977-82) of the programme.

TABLE VI-Relative net reductions $\dagger$ in North Karelia in risk factor means in men and women aged 30-59 years in 1972-7 and 1972-82. Values are percentages

\begin{tabular}{lrcrlc}
\hline & \multicolumn{2}{c}{ Men } & & \multicolumn{2}{c}{ Women } \\
\cline { 2 - 3 } \cline { 5 - 6 } & $1972-7$ & $1972-82$ & & $1972-7$ & $1972-82$ \\
\hline Daily smoking & $15(10)^{* *}$ & $28(11)^{* * *}$ & & $12(27)$ & $14(38)$ \\
Serum cholesterol & $4(1)^{* * *}$ & $3(2)^{* * * *}$ & & $1(2)$ & $1(2)$ \\
Systolic blood pressure & $3(1)^{* * *}$ & $3(1)^{* * * *}$ & & $5(1)^{* * *}$ & $5(1)^{* * *}$ \\
Diastolic blood pressure & $3(1)^{* * *}$ & $1(1)^{* *}$ & & $4(1)^{* * *}$ & $2(1)^{*}$
\end{tabular}

${ }^{*} \mathrm{p}<0.05 . \quad{ }^{* *} \mathrm{p}<0.01 . \quad{ }^{* * *} \mathrm{p}<0.001$

†North Karelia 1982/77-1972) - (reference area 1982/77-1972)/North Karelia 1972 with $95 \%$ confidence interval. Statistical significance based on two way ANCOVA with covariance adjustment for age.

\section{Discussion}

The main objective of the North Karelia project was to carry out and evaluate a comprehensive community based intervention programme aimed at reducing rates of cardiovascular disease by reducing the well established risk factors. Because the risk factors are closely linked with the general life styles and social settings of the community the intervention concerned the whole population and the entire community of North Karelia. The assessment of the effect of the intervention was based on repeated independent surveys of large representative population samples in North Karelia and in a matched reference area at the outset (spring 1972), at the end of the first five year period (spring 1977), and at the end of 10 years (spring 1982). The net reduction in North Karelia (the reduction in North Karelia minus the reduction in the reference area) was considered to be the programme effect.

This community based approach with a quasi-experimental study design ${ }^{14}$ differs in many ways from the classical intervention trial based on random allocation of subjects into experimental and control groups. A classical trial has several well known limitations. An individual clinical type of intervention on risk factors deals with people outside their natural living conditions; it is expensive and the results may be difficult to apply nation wide. A community based approach that tests the effects of a comprehensive package in natural conditions overcomes these problems to a great extent. It uses more "real life" intervention with existing service structure and community participation and takes advantage of natural interactions of several variables in the community. It may reduce costs significantly and obviate ethical problems which might otherwise exist.

A community based study is not primarily designed to test the possible causal relation between risk factors and disease. Nevertheless, because of the limitations of randomised trials and the advantages of community programmes, these may give considerable information about the role of conventional risk factors. Community programmes have other important roles as well. They demonstrate our ability to modify levels of risk factors in the population and test the feasibility of such pro- grammes using existing health service and other resources. Furthermore, they serve as demonstration and training models. ${ }^{15}$

Participation rates in our surveys were relatively high. Rates in the follow up surveys were somewhat smaller than at the outset, probably owing to the increased number of screening examinations in the areas, especially in North Karelia. Similar self administered and precoded questionnaires were used in all three surveys. Measurements were carried out by specially trained nurses who were carefully instructed and trained in the use of standardised and internationally accepted techniques. Strenuous efforts were made to use identical procedures in the two areas and in all three surveys.

The validity of a smoking history may be reduced by incorrect self reporting. Results from a subsample interview and the serum thiocyanate analysis in 1977 , however, suggested that our results were reasonably valid. ${ }^{7}$ In the 1982 survey serum thiocyanate was analysed in every participant. These analyses showed no major differences between the two areas in the validity of self reported smoking.

The changes in risk factors in North Karelia and the reference area during the first five year period have been analysed before, both among separate samples but in same population birth cohort (aged 25-59 at the outset) and in separate samples but the same age range in 1972 and in 1977 (30-59), and also among a smaller cohort of the same people. ${ }^{71011}$ All these approaches gave essentially the same results: in 1972-7 there was a clear net reduction in risk factor levels in North Karelia, and it was greater among men than among women.

The favourable changes in risk factor levels observed in North Karelia and also the reference area at both the five year and 10 year surveys represent national trends and interest in modifying life style. The North Karelia project, however, has clearly in many ways contributed to these changes through government mass media and other activities. ${ }^{16}$

The 10 year follow up survey was carried out in North Karelia to see whether the improved risk factor levels achieved during the initial five years had returned to their former level, had been maintained, or had improved still further. The survey was also repeated in the reference area to see whether that area had caught up with North Karelia, or whether the same difference remained, or whether the more favourable trend had continued in North Karelia. In the 1982 survey further measures were also taken to assess the validity of these important findings. The results showed that during the second five year period smoking and serum cholesterol concentrations had further decreased among men in North Karelia. For smoking the net reduction had increased further, and for serum cholesterol the net reduction achieved in 1977 was maintained. Among women smoking had increased and the serum cholesterol concentration decreased in North Karelia during 1977-82, but the net difference remained much the same as during the first five year period.

For blood pressure little progress took place after 1977. It should, however, be noted that in 1982 a longer cuff was used. Since this may have resulted in lower mean values than would have been the case with the cuff used in 1972 and 1977, an increase in absolute blood pressure might have occurred at least for systolic blood pressure, in both areas. This question will be examined in more detailed reports on the blood pressure results. The difference between North Karelia and the reference area, however, remained for systolic blood pressure. For diastolic blood pressure the difference achieved in 1977 became less but did not disappear in 1982 .

Overall the reductions in risk factor levels observed in North Karelia during the 10 years of the programme were substantial: for men $36 \%$ in smoking, $11 \%$ for mean serum cholesterol concentration, and 5\% for mean diastolic blood pressure. The changes in biological risk factors (serum cholesterol and blood pressure) were much smaller than in smoking, which is to be expected. These changes in risk factors may be considered small for an individual, but they represent mean changes for the whole population and should thus be important for population disease rates. The changes in biological risk factors among women were 
similar to those among men, but the results for smoking were bound to differ because of the small initial smoking rates among women.

Risk factor levels were also clearly reduced in the reference area, as had been observed during the first five year period. At that time, however, the reduction had been greater in North Karelia among men for all risk factors and among women for blood pressure. During continued follow up the net difference in favour of North Karelia further increased for smoking, remained the same for serum cholesterol concentration and systolic blood pressure, and lessened for diastolic blood pressure. Thus the results in 1982 were further evidence of the effects of the intervention programme in North Karelia.

These results indicate that a long term reduction in population risk factor levels has, indeed, taken place in the county of North Karelia as a consequence of a community based intervention programme. It is obviously difficult to state the reasons for this effect and whether and how it could be accomplished elsewhere. A community programme like this is ultimately designed to test whether a specific programme as a whole (which should be designed so that it can be applied on a larger scale) is feasible and effective under given conditions. The impact of various community conditions and of different components of the project on successes and failures can be evaluated only to a limited extent.

In considering the application of the present results it is clear that the great magnitude of the problem in the area (but also in the reference area), the Finnish health service system, and cultural factors have contributed to the achievement in North Karelia. But the results do show the potential of the community based approach. Naturally, intervention programmes in other communities will need to be specially designed and based on sound behavioural principles. In North Karelia great concern was expressed at the planning stage because of the rural, low socioeconomic nature of the area, with high unemployment, few medical resources, and much dairy farming, which influenced the actual strategy of the intervention developed. ${ }^{917}$

It is interesting to compare these effects on risk factors in the North Karelia project with those observed in some recent major risk factor intervention studies. Compared with the six year results of a study in the United States the results in North Karelia are somewhat greater for smoking and for serum cholesterol but slightly smaller for diastolic blood pressure. ${ }^{18}$ Thus the overall impact of community based intervention appeared greater in North Karelia despite the fact that the American study was concerned with only some 6500 high risk men who were each intervened upon with considerable clinical intensity and, accordingly, high cost. This supports some of the advantages of the community based approach as mentioned above.

The overall results in North Karelia also seem to be considerably better than the results of the British heart disease prevention project, even when only high risk subjects in that study are considered. ${ }^{19}$ The results of the Belgian project were also somewhat better than in Britain, but still smaller than in North Karelia, especially at six years of follow up. ${ }^{20}$ In the Oslo study the effect of the intervention on smoking and serum cholesterol was greater than in North Karelia. ${ }^{21}$ In that study, however, the intervention concerned only about 600 men with very high initial values and the intervention was carried out in only one centre by a few devoted professionals.

Analysis of the latest available mortality data showed that the decline in coronary mortality increased towards the end of the 1970 s in North Karelia. The decline was greater than in the reference area or in the rest of Finland. The reduction in mortality from coronary heart disease among the male population in North Karelia is now significantly greater than in the rest of the country. ${ }^{12}$ Thus it is possible that the impact of the programme starts to show after some delay also for the main objective-reduced mortality.

We conclude that well conceived community based programmes may have an important impact on life styles and cardiovascular risk factor levels in the population. With a sustained programme it is also possible to maintain these more favourable levels over a long period. Such a development is interrelated with and may contribute to nationwide change and result in reduced rates of cardiovascular disease and improved health among the population.

\section{References}

${ }^{1}$ Keys A. Coronary heart disease in seven countries. American Heart Association Monograph 1970;No 29.

${ }^{2}$ World Health Organisation. Myocardial infarction community registers. Public health in Europe 5. Copenhagen, WHO/EURO:1976.

${ }^{3}$ Pisa Z, Uemura K. Trends of mortality from ischaemic heart disease and other cardiovascular diseases in 27 countries, 1968-77. World Health Stat $Q 1982 ; 35: 11-47$.

${ }^{4}$ Puska P. Regional differences in CVD mortality in Finland. Suomen Lääkärilehti 1972;27:3193-6. (In Finnish.)

${ }^{5}$ Puska P, Mustaniemi H. Incidence and presentation of myocardial infarction in North Karelia, Finland. Acta Med Scand 1975;197:211-6.

${ }^{6}$ Puska P. The North Karelia project : an attempt at community prevention of cardiovascular disease. WHO Chron 1973;27:55-8.

7 Puska P, Tuomilehto J, Salonen J, et al. The North Karelia project: evaluation of a comprehensive community programme for control of cardiovascular diseases in 1972-77 in North Karelia, Finland. Copenhagen: WHO, 1981.

${ }^{8}$ Tuomilehto J, Puska P, Virtamo J, Salonen J, Koskela K. The levels of the major risk indicators of cardiovascular diseases in Eastern Finland prior to a community-based intervention programme (the North Karelia project). Acta Cardiol 1979;34:359-74.

${ }^{9}$ McAlister A, Puska P, Salonen JT, Tuomilehto J, Koskela K. Theory and action for health promotion. Illustrations from the North Karelia project. Am $\mathcal{F}$ Public Health 1982;72:43-50.

${ }_{10}$ Puska P, Tuomilehto J, Salonen JT, et al. Changes in coronary risk factors during comprehensive five-year community programme to control cardiovascular diseases (North Karelia project). Br Med $\mathcal{f}$ 1979;ii: 1173-8.

"Salonen JT, Puska P, Kottke TE, Tuomilehto J. Changes in smoking, serum cholesterol and blood pressure levels during a community-based cardiovascular disease prevention programme: the North Karelia project. Am $\mathcal{F}$ Epidemiol $1981 ; \mathbf{1 1 4}: 81-94$.

12 Salonen JT, Puska P, Kottke TE, Tuomilehto J, Nissinen A. The decline in coronary mortality in North Karelia in 1969-79-a cross-area analysis. Br Med f 1983;286:1857-60.

13 World Health Organisation. Proposal for the multinational monitoring of trends and determinants in cardiovascular disease and protocol (MONICA project). Geneva: WHO (EHO/MNC/82.1)

${ }^{14}$ Campbell DT, Stanley JC. Experimental and quasi-experimental designs for research. Chicago: Rand McNally and Co, 1963.

${ }^{15}$ Farquhar JW. The community-based model of life style intervention trials. Am $\mathcal{F}$ Epidemiol 1978;108:103-11.

16 Puska P, McAlister A, Pekkola J, Koskela K. Television in health promotion. Evaluation of a national programme in Finland. Int $\mathcal{F}$ Health Educ $1981 ; \mathbf{2 4}: 2-14$

17 Tuomilehto J, Puska P, Virtamo J, Neittaanmäki L, Koskela K. Coronary risk factors and socioeconomic status in eastern Finland. Prev Med 1978; 7:539-49.

18 Multiple Risk Factor Intervention Trial Research Group. Multiple risk factor intervention trial. Risk factor changes and mortality results. fAMA $1982 ; 248: 1465-77$.

19 Rose G, Tunstall-Pedoe HD, Heller RF. UK heart disease prevention project : incidence and mortality results. Lancet 1983; ; :1062-6.

20 Kornitzer $M$, De Backer $G$, Dramaix $M$, et al. Belgian heart disease prevention project: incidence and mortality results. Lancet 1983; : 1066-70.

${ }^{21}$ Hjerman I, Velve Byre K, Holme I, Leren P. Effect of diet and smoking intervention on the incidence of coronary heart disease. Report from the Oslo study group of a randomized trial in healthy men. Lancet 1981; ii : $1303-10$.

(Accepted 3 October 1983) 